\title{
Improved clonal approaches to growing black locust (Robinia pseudoacacia L.) in Hungary: a case study
}

\author{
Rédei, K. ${ }^{1}$, Keserü, ZS. ${ }^{1}$ \& Antal, B. ${ }^{2}$ \\ ${ }^{1}$ Department of Plantation Forestry, National Agricultural Research and Innovation Center \\ Forest Research Institute, Sárvár, Hungary \\ ${ }^{2}$ Faculty of Agriculture, University of Debrecen, Hungary \\ Correspondence: E-mail: redei.karoly@t-online.hu
}

\begin{abstract}
Summary: In Hungary black locust (Robinia pseudoacacia L.) is considered as an important exotic stand-forming tree species and due to climate change effects its importance is increasing in many other countries. It has some desirable characteristics from both the practical and research standpoints. As a result of a partly new black locust selection programme new black locust clones were improved and a technology was developed for mass clonal micropropagation of juvenile trees. Clone trials with micropropagated plants were established in the country for evaluating the juvenile growth and the stem form of promising black locust clones under marginal site conditions. Significant differences $(\mathrm{P}<5 \%)$ were found for stem form value which partly verified the genetic gain of the selected clones against the common black locust. It was also proved that tissue culture could offer partly new prospects for the rapid mass cloning of selected genotypes.
\end{abstract}

Keywords: black locust (Robinia pseudoacacia L.), juvenile growth, micropropagation

\section{Introduction}

Black locust (Robinia pseudoacacia L.) was introduced to Hungary about 300 years ago and at present it covers approximately 23 per cent of the forested lands (465 000 ha). It has been well adapted for growth in a wide variety of ecological conditions and planted throughout the world from temperate to subtropical areas. It is fast growing, excellent coppicing, drought tolerant, has high survival rates and yield as well as very hard durable wood (Rédei et al. 2002). Due to its symbiosis with the nitrogen fixing bacteria, Rhizobium sp. black locust is capable of colonising very low nutrient substrates. Black locust is also a promising tree species for short rotation forestry (SRF) including energy plantations (Rédei et al. 2002, 2008).

Besides Hungary black locust breeding and improvement is undertaken in the United States (Bongarten et al. 1991, 1992), Greece (Dini-Papanastasi \& Panetsos 2000), Germany (Liesebach et al. 2004, Böhm et al. 2011), Slovakia (Chalupa 1992), Poland (Kraszkiewicz 2013), Turkey (Dengiz et al. 2010), India (Sharma 2000), China (Dunlun et al. 1995) and South Korea (Lee et al. 2007).

Brown (1980) was the first to report a successful in vitro method for mass production of black locust. Enescu \& Jucan (1985) started experiments in Romania with similar results. Balla \& Vértesy in 1985 had the first success in the sterile production of some Hungarian state-approved black locust cultivars. Balla et al. (1998) published the improvement of the acclimatization results of micropropagated black locust using symbiotic microorganisms which have proved to be successful in the field of mass clonal micropropagation (Rédei et al. 2002). Finally, a summary on black locust micropogation techniques was published by Jain et al. (2007).

In this paper a field trial established with micropropagated black locust clones is evaluated with special regard to their propagation technique and juvenile growth.

\section{Materials and methods}

\section{Study site}

Data used in this study came from a black locust clone trial established in the forest subcompartment located at Isaszeg 8D, central Hungary (N47 $33^{\prime} 5.88^{\prime \prime}$, E19 $23{ }^{\prime} 58.71$ "). It has brown forest soil without groundwater influence. The annual precipitation amounts to only $500 \mathrm{~mm}$ in some years, of which less than $350 \mathrm{~mm}$ comes in the dry summer period.

\section{Materials}

The trial, with three replications was established at a spacing of $2.0 \mathrm{~m} \times 1.0 \mathrm{~m}$. Three black locust clones, i.e. 'CST 
61A 3/1', 'KH 56A 2/6' and 'MB 12D' as well as common black locust as a control were planted. Each treatment corresponds to a plot of 15 by $20 \mathrm{~m}$. A random block was designed where each block included all the different treatments (clones) once. It means that the total number of plants per clone was 450 . For the clones one-year-old micropropagated plants were used and one-year-old seedlings for common black locust.

\section{Methods}

The following parameters were measured and calculated: number of stems, tree height, dbh (diameter at breast height) over bark, stem volume and mean tree volume. The stem volume was calculated using the following volume function based on the volume table for black locust (Kolozs \& Sopp 2000):

$$
v=10^{-8} \mathrm{~d}^{2} \mathrm{~h}^{1}(\mathrm{~h} /[\mathrm{h}-1.3])^{2}(-0.6326 \mathrm{dh}+20.23 \mathrm{~d}+3034),
$$

where $\mathrm{v}$ is stem volume $\left(\mathrm{m}^{3}\right), \mathrm{d}$ is diameter at breast height $(\mathrm{cm}), \mathrm{h}$ is tree height $(\mathrm{m})$. The mean tree volume $\left(\mathrm{v}, \mathrm{m}^{3} /\right.$ tree) was calculated using the means of stem volume $(\mathrm{h}, \mathrm{dbh})$ for each of the experimental plots (Rédei et al. 2013).

The stem form classes used by us are as follows at the age of final harvesting: 1) Straight, cylindrical, healthy stems, reaching to the top of the crown. Crooks are tolerated in one dimension only, not more than twice the stem diameter $\left(\mathrm{x}_{1}\right)$. 2) The stem is straight, forks are tolerated, but only if they are in the uppermost third of the tree. Crooks are tolerated in one dimension only, not more than three times the stem diameter $\left(\mathrm{x}_{2}\right)$. 3) The stem is crooked and leaning. Crooks may reach five times the stem diameter in one dimension and minor crookedness in a second dimension is tolerated $\left(\mathrm{x}_{3}\right)$. 4) Very crooked in more than one dimension, low branching, forked trees with stem defects, broken crown or stem rot $\left(\mathrm{x}_{4}\right)$ (Rédei et al. 2013).

The average stem form value (SFV) was determined on base of the following formula:

$$
\mathrm{SFV}=\frac{x_{1} n_{1}+x_{2} n_{2}+x_{3} n_{3}+x_{4} n}{n_{1}+n_{2}+n_{3}+n_{4}}
$$

where $x_{1}, x_{2}, x_{3}, x_{4}=$ stem form classes,

$n_{1}, n_{2}, n_{3}, n_{4}=$ tree numbers belonging to the single tree quality classes.

The data were analyzed by IBM SPSS 22.0 statistical software package. Analysis of variance (one-way ANOVA) was done for height, dbh, mean tree volume and stem form to consider the trial with having completely randomized design. Post hoc tests were made by Tukey's HSD test.

\section{Results}

Table 1 illustrates the most important stand structure parameters and the stem form values at age of 7 years. Comparison of mean height illustrated that clone ' $\mathrm{KH} 56$ A 2/6' achieved the higher value $(8.4 \mathrm{~m})$. Comparison of mean DBH indicated that the clone 'CST 61A 3/1' had the maximum growth. The same result was obtained in the case of mean tree volume for 'CST 61A 3/1', too. 'CST 61A 3/1' and 'KH 56 A 2/6' clones had the best stem form values.

As shown in Table 2 analysis of variance for mean height (h), mean diameter at breast height (dbh) and the mean tree volume (v) at the end of the $7^{\text {th }}$ growing seasons did not, but the stem values (SFV) - the main purpose of selection trials showed statistically significant differences $(\mathrm{p}<0.05)$ between two clones ('CST 61A 3/1', 'KH 56 A 2/6') and the control.

\section{Discussions}

In the past years black locust has received increased attention in more countries for the following reasons: (1) the global climate change and energy crisis have stimulated research on rapid growing but relatively drought tolerant tree species; (2) some countries such as Hungary, Romania, France, Germany, Korea and China are vigorously developing the species; and (3) the species has a lot of desirable characteristics from plantation management point of view.

The purpose of this paper, as the title implies, is to give initial information on a partly new black locust selection programme in Hungary, so there have not been too many comparable field research results for a wide-ranging discussion yet. As it is mentioned above, in Hungary the main goal of black locust improvement is to grow high-yielding plantations under semi-arid and arid site conditions. Some improved clones may be fast-growing or drought-resistant, but rarely both. It must be also considered that any improvement 
Table 2: Results of Tukey's HSD test of the micropropagated black locust clones' stand characteristics

\begin{tabular}{|c|c|c|c|c|c|c|c|}
\hline \multirow{2}{*}{$\begin{array}{l}\text { Dependent } \\
\text { Variable }\end{array}$} & \multirow{2}{*}{ (I) Clone } & \multirow{2}{*}{ (J) Clone } & \multirow{2}{*}{$\begin{array}{c}\text { Mean } \\
\text { Difference } \\
\quad(\mathrm{I}-\mathrm{J})\end{array}$} & \multirow{2}{*}{ Std. Error } & \multirow{2}{*}{ Sig. } & \multicolumn{2}{|c|}{$\begin{array}{l}\text { 95\% Confidence } \\
\text { Interval }\end{array}$} \\
\hline & & & & & & $\begin{array}{l}\text { Lower } \\
\text { Bound }\end{array}$ & $\begin{array}{l}\text { Upper } \\
\text { Bound }\end{array}$ \\
\hline \multirow[t]{12}{*}{ Height } & \multirow{3}{*}{$\begin{array}{l}\text { CST } 61 \\
\text { A } 3 / 1\end{array}$} & КH 56A 2/6 & $-0,2667$ & 0,3291 & 0,8481 & $-1,3207$ & 0,7874 \\
\hline & & MB12 D & 0,5000 & 0,3291 & 0,4702 & $-0,5540$ & 1,5540 \\
\hline & & Control & 0,3000 & 0,3291 & 0,7997 & $-0,7540$ & 1,3540 \\
\hline & \multirow{3}{*}{$\begin{array}{l}\text { KH 56A } \\
2 / 6\end{array}$} & CST 61 A 3/1 & 0,2667 & 0,3291 & 0,8481 & $-0,7874$ & 1,3207 \\
\hline & & MB12 D & 0,7667 & 0,3291 & 0,1701 & $-0,2874$ & 1,8207 \\
\hline & & Control & 0,5667 & 0,3291 & 0,3733 & $-0,4874$ & 1,6207 \\
\hline & \multirow[t]{3}{*}{ MB12 D } & CST 61 A 3/1 & $-0,5000$ & 0,3291 & 0,4702 & $-1,5540$ & 0,5540 \\
\hline & & KH 56A 2/6 & $-0,7667$ & 0,3291 & 0,1701 & $-1,8207$ & 0,2874 \\
\hline & & Control & $-0,2000$ & 0,3291 & 0,9268 & $-1,2540$ & 0,8540 \\
\hline & \multirow[t]{3}{*}{ Control } & CST 61 A 3/1 & $-0,3000$ & 0,3291 & 0,7997 & $-1,3540$ & 0,7540 \\
\hline & & KH 56A 2/6 & $-0,5667$ & 0,3291 & 0,3733 & $-1,6207$ & 0,4874 \\
\hline & & MB12 D & 0,2000 & 0,3291 & 0,9268 & $-0,8540$ & 1,2540 \\
\hline \multirow[t]{12}{*}{$\mathrm{DBH}$} & \multirow{3}{*}{$\begin{array}{l}\text { CST } 61 \\
\text { A } 3 / 1\end{array}$} & KH 56A 2/6 & 0,1333 & 0,4410 & 0,9897 & $-1,2788$ & 1,5454 \\
\hline & & MB12 D & 0,5000 & 0,4410 & 0,6806 & $-0,9121$ & 1,9121 \\
\hline & & Control & 0,5667 & 0,4410 & 0,5960 & $-0,8454$ & 1,9788 \\
\hline & \multirow{3}{*}{$\begin{array}{l}\text { KH 56A } \\
2 / 6\end{array}$} & CST 61 A 3/1 & $-0,1333$ & 0,4410 & 0,9897 & $-1,5454$ & 1,2788 \\
\hline & & MB12 D & 0,3667 & 0,4410 & 0,8383 & $-1,0454$ & 1,7788 \\
\hline & & Control & 0,4333 & 0,4410 & 0,7630 & $-0,9788$ & 1,8454 \\
\hline & \multirow[t]{3}{*}{ MB12 D } & CST 61 A 3/1 & $-0,5000$ & 0,4410 & 0,6806 & $-1,9121$ & 0,9121 \\
\hline & & KH 56A 2/6 & $-0,3667$ & 0,4410 & 0,8383 & $-1,7788$ & 1,0454 \\
\hline & & Control & 0,0667 & 0,4410 & 0,9987 & $-1,3454$ & 1,4788 \\
\hline & \multirow[t]{3}{*}{ Control } & CST 61 A 3/1 & $-0,5667$ & 0,4410 & 0,5960 & $-1,9788$ & 0,8454 \\
\hline & & KH 56A 2/6 & $-0,4333$ & 0,4410 & 0,7630 & $-1,8454$ & 0,9788 \\
\hline & & MB12 D & $-0,0667$ & 0,4410 & 0,9987 & $-1,4788$ & 1,3454 \\
\hline \multirow{12}{*}{$\begin{array}{l}\text { Mean tree } \\
\text { volume }\end{array}$} & \multirow{3}{*}{$\begin{array}{l}\text { CST } 61 \\
\text { A 3/1 }\end{array}$} & KH 56A 2/6 & 0,0003 & 0,0021 & 0,9985 & $-0,0064$ & 0,0071 \\
\hline & & MB12 D & 0,0027 & 0,0021 & 0,5963 & $-0,0040$ & 0,0094 \\
\hline & & Control & 0,0024 & 0,0021 & 0,6761 & $-0,0043$ & 0,0091 \\
\hline & \multirow{3}{*}{$\begin{array}{l}\text { KH 56A } \\
2 / 6\end{array}$} & CST 61 A 3/1 & $-0,0003$ & 0,0021 & 0,9985 & $-0,0071$ & 0,0064 \\
\hline & & MB12 D & 0,0024 & 0,0021 & 0,6850 & $-0,0044$ & 0,0091 \\
\hline & & Control & 0,0021 & 0,0021 & 0,7627 & $-0,0047$ & 0,0088 \\
\hline & MB12 D & CST 61 A 3/1 & $-0,0027$ & 0,0021 & 0,5963 & $-0,0094$ & 0,0040 \\
\hline & & KH 56A 2/6 & $-0,0024$ & 0,0021 & 0,6850 & $-0,0091$ & 0,0044 \\
\hline & & Control & $-0,0003$ & 0,0021 & 0,9989 & $-0,0070$ & 0,0064 \\
\hline & Control & CST 61 A 3/1 & $-0,0024$ & 0,0021 & 0,6761 & $-0,0091$ & 0,0043 \\
\hline & & KH 56A 2/6 & $-0,0021$ & 0,0021 & 0,7627 & $-0,0088$ & 0,0047 \\
\hline & & MB12 D & 0,0003 & 0,0021 & 0,9989 & $-0,0064$ & 0,0070 \\
\hline & CST 61 & KH 56A 2/6 & $-0,1000$ & 0,1374 & 0,8834 & $-0,5401$ & 0,3401 \\
\hline & A $3 / 1$ & MB12 D & $-0,3667$ & 0,1374 & 0,1063 & $-0,8068$ & 0,0735 \\
\hline & & Control & $-0,7000^{*}$ & 0,1374 & 0,0041 & $-1,1401$ & $-0,2599$ \\
\hline Stem form & KH 56A & CST 61 A 3/1 & 0,1000 & 0,1374 & 0,8834 & $-0,3401$ & 0,5401 \\
\hline$(\mathrm{SFV})$ & & MB12 D & $-0,2667$ & 0,1374 & 0,2851 & $-0,7068$ & 0,1735 \\
\hline & & Control & $-0,6000^{*}$ & 0,1374 & 0,0103 & $-1,0401$ & $-0,1599$ \\
\hline & & CST 61 A 3/1 & 0,3667 & 0,1374 & 0,1063 & $-0,0735$ & 0,8068 \\
\hline & MB12 D & KH 56A 2/6 & 0,2667 & 0,1374 & 0,2851 & $-0,1735$ & 0,7068 \\
\hline & & Control & $-0,3333$ & 0,1374 & 0,1491 & $-0,7735$ & 0,1068 \\
\hline & & CST 61 A 3/1 & $0,7000 *$ & 0,1374 & 0,0041 & 0,2599 & 1,1401 \\
\hline & Control & KH 56A 2/6 & $0,6000 *$ & 0,1374 & 0,0103 & 0,1599 & 1,0401 \\
\hline & & MB12 D & 0,3333 & 0,1374 & 0,1491 & $-0,1068$ & 0,7735 \\
\hline
\end{tabular}

*The mean difference is significant at $\mathrm{p}<0.05$ level. from tree breeding and selection are likely to be small and slow. It can be found out from the relevant international literature that very few clone trials have been set up with micropropagated black locust plants up till now. The reason may be the lack of practice - oriented research results and experiences relating to the subject.

This study leads to the following conclusions: (1) micropropagated trees exhibited normal growth and appearance; (2) the results at the end of the $7^{\text {th }}$ growing season demonstrated that the selection's main purpose, the stem form values differed significantly among two tested clones ('CST 61A 3/1','KH 56 A 2/6') and the control; (3) the investigations showed that clones 'CST 61A 3/1' and 'KH 56 A 2/6' achieved the highest growth rate in mean tree volume with having the best morphological characteristics; (4) micropropagation has proved as a suitable mean in the field of black locust clonal selection under marginal site condition as well.

\section{Acknowledgements}

The authors gratefully acknowledge the valuable comments on the manuscript made by Heike Liesebach PhD, Thünen Institute of Forest Genetics, Grosshansdorf, Germany.

\section{References}

Balla, I. \& Vértesy J. (1985): Experiences and problems related to the micropropagation of black locust. In: Symposium on In Vitro Problems Related to Mass Propagation of Horticultural Plants, Book of Abstracts II. International Society of Horticultural Science, Gembloux, Belgium.

Balla, I., Vértesy, J., Köves-Pécsi, K., Vörös, I., Osváth-Bujtás, Z. \& Bíró, B. (1998): Acclimation results of micropropagated black locust (Robinia pseudoacacia L.) improved by symbiotic microorganism. Plant Cell Tissue Organ Culture, 52: 113-115.

Böhm, Ch., Quinkenstein, A. \& Freese D. (2011): Yield prediction of young black locust (Robinia pseudoacacia L.) plantation for woody biomass production using allometric relations. Annals of Forest Research, 54 (2): 215-227.

Bongarten, B.C., Merkle, S.A. \& Hanover J.W. (1991): Genetically improved black locust for biomass production in short-rotation plantations. In: Klass D.L. ed., Energy from Biomass and Wastes XV, Institute of Gas Technology, Chicago, IL. pp. 391-409 
Bongarten, B.C., Huber, D.A. \& Apsley, D.K. (1992): Environmental and genetic influences on short-rotation biomass production of black locust (Robinia pseudoacacia L.) in the Georgia Piedmont. Forest Ecology and Management, 55: 315-331.

Brown, C. L. (1980): Application of tissue culture technology to production of woody biomass. In: J. M. Bonga, D. J. Durzan (eds.), Tissue Culture in Forestry. Martinus Nijhoff, The Hague, pp. 137-145.

Chalupa, V. (1992): Tissue culture propagation of black locust. [In: Hanover J.W., Miller K., Plesko S. eds., Black locust: Biology, Culture and Utilization.] Michigan State University, East Lansing, pp. 115-125.

Dengiz, O., Gol, C., Sarioglu, F. E. \& Edis S. (2010): Parametric approach to land evaluation for forest plantation: A methodological study using GIS model. African Journal of Agricultural Research, 5 (12): 1482-1496.

Dini-Papanastasi, O. \& Panetsos C.P. (2000): Relation between growth and morphological traits and genetic parameters of Robinia pseudoacacia var. monophylla DC in northern Greece. Silvae Genetica, 49: 37-44.

Dunlun, Z., Zhenfen, Z. \& Fangquan W. (1995): Progress in clonal selection and breeding of black locust (Robinia pseudoacacia L.) [In: Forest Tree Improvement in the Asia-Pacific Region (Xihuan Shen):] China Forestry Publishing House, Beijing, pp. 152-156

Enescu, V. \& Jucan A. (1985): Problems of the in vitro micropropagation of black locust (Robinia pseudoacacia L.). [In: Caron F., Corriveau A. G., Boyle T. J. B. (eds.), New Ways in Forest Genetics: Proceeding of the $20^{\text {th }}$ Canadian Tree Improvement Association Meeting,] Quebec. pp. 179-184.

Jain, S. M. \& Haggman H. (2007): Micropropagation of Black Locust (Robinia Pseudoacacia L.), Springer, pp. 193-199.
Kolozs, K. \& Sopp L. (2000): Volume Tables. Agricultural Publishing House, Budapest, Hungary.

Kraszkiewicz, A. (2013): Evaluation of the possibility of energy use black locust (Robinia pseudoacacia L.) dendromass acquired in forest stands growing on clay soils. Journal of Central European Agriculture, 14 (1): 388-399.

Lee, K. J., Sohn, J. H., Rédei, K. \& Yun, H. Y. (2007): Selection of Early and Late Flowering Robinia pseudoacacia from Domesticated and Introduced Cultivars in Korea and Prediction of Flowering Period by Accumulated Temperature. Journal of Korean Forest Society, 96 (2): 170-177.

Liesebach, H., Yang, M.S. \& Schneck, V. (2004): Genetic diversity and differentiation in a black locust (Robinia pseudoacacia L.) progeny test. Forest Genetics, 11 (2): 151-161.

Rédei, K., Osváth-Bujtás, Z. \& Balla, I. (2002): Clonal approaches to growing black locust (Robinia pseudoacacia) in Hungary: a review. Forestry, 75 (5): 547-552.

Rédei, K., Osváth-Bujtás, Z. \& Veperdi, I. (2008): Black Locust (Robinia pseudoacacia L.) Improvement in Hungary: a Review. Acta Silvatica et Lignaria Hungarica, 4:127-132.

Rédei, K., Csiha, I., Keserü, ZS., Kamandiné Végh, Á. \& Győri, J. (2011): The Silviculture of Black Locust (Robinia pseudoacacia L.) in Hungary: a Review. South-east European forestry, 2 (2): 101-107.

Rédei, K., Keserü, ZS. \& Rásó, J. (2013): Early evaluation of micropropagated black locust (Robinia pseudoacacia L.) clones in Hungary. Forest Science and Practice, 15 (1): 81-84.

Sharma, K.R. (2000): Variation in wood characteristics of Robinia pseudoacacia L. managed under high density short rotation system. IUFRO World Congress held in Malaysia. 